\title{
GAMBARAN FUNGSI AFEKTIF KELUARGA DAN PERILAKU SEKSUAL REMAJA
}

\author{
Yesi Gustiani $^{1 *}$, Titin Ungsianik ${ }^{2}$ \\ 1. Rumah Perawatan Luka, Cikarang Barat, Bekasi 17530, Indonesia \\ 2. Fakultas Ilmu Keperawatan Universitas Indonesia, Kampus UI, Depok 16424, Indonesia \\ *E-mail: yesigustiani@gmail.com
}

\begin{abstract}
Abstrak
Remaja adalah populasi yang rentan mengalami masalah seksual dan perlu mendapat perhatian khusus. Penelitian ini bertujuan memberikan gambaran fungsi afektif keluarga dan perilaku seksual remaja di salah satu Sekolah Menengah Kejuruan (SMK) Negeri di Kota Depok. Metode penelitian ini adalah deskriptif sederhana dengan desain cross sectional, melibatkan 114 siswa yang dipilih dengan cluster sampling. Instrumen yang digunakan pada penelitian ini adalah instrumen perilaku remaja dan instrumen fungsi afektif keluarga yang dimodifikasi dari penelitian sebelumnya. Hasil penelitian menunjukkan mayoritas responden memiliki fungsi afektif keluarga adekuat dan perilaku seksual remaja berisiko rendah. Direkomendasikan adanya konseling fungsi afektif keluarga kepada orang tua serta penyuluhan kesehatan reproduksi pada siswa dan siswi oleh tenaga kesehatan untuk menghindari perilaku seksual berisiko pada remaja.
\end{abstract}

Kata kunci: fungsi afektif keluarga, kesehatan reproduksi, perilaku seksual, remaja

\begin{abstract}
The Affective Function of the Family and the Adolescent's Sexual Behavior. Adolescent is susceptible to various sexual problems that may require special attention. The purpose of this research was to describe the family's affective functions and the adolescent's sexual behavior in one of public vocational high schools in Depok City. The study method was simple descriptive with cross sectional approach, involving 114 students, selected by cluster sampling. The result showed that the majority of students had an adequate family's affective function and a low risk of adolescent's sexual behavior. Researcher recommended parents to have a counseling of family's affective function and health professionals to give a reproductive health education to students in order to reduce the risky sexual behaviors in adolescents.
\end{abstract}

Keywords: adolescent, family's affective functions, reproductive health, sexual behavior

\section{Pendahuluan}

Jumlah remaja Indonesia yaitu $26,67 \%$ dari total penduduk Indonesia (Badan Pusat Statistik, 2010). Remaja akan berpengaruh terhadap pembangunan berbagai aspek termasuk aspek sosial, ekonomi maupun demografi baik saat ini maupun di masa yang akan datang sehingga remaja perlu mendapat perhatian agar terhindar dari berbagai masalah yang berisiko. Beberapa masalah yang sering muncul pada remaja diantaranya masalah seksualitas, penyalahgunaan Narkotika, psikotropika dan zat adiktif lainnya (NAPZA) dan HIV/AIDS (Badan Kependudukan dan Keluarga Berencana Nasional [BKKBN], 2011; United States Agency for International Development [USAID], 2013).

Survey Kesehatan Reproduksi Remaja Indonesia (SKRRI) tahun 2002-2003 menemukan remaja yang pernah berhubungan seksual pada usia 14-19 tahun untuk perempuan sebanyak $34,7 \%$ dan laki-laki sebanyak $30,9 \%$. Sedangkan pada tahun 2007 mengenai pengalaman berpacaran, umur pertama kali berpaca- 
ran pada wanita maupun pria sebagian besar pada usia 15-17 tahun, proporsi wanita lebih tinggi $43 \%$ dibanding pria $40 \%$. Perilaku seksual yang sering dilakukan remaja dalam berpacaran pada remaja wanita, yaitu berpegangan tangan $69 \%$, berciuman bibir $41 \%$, meraba atau merangsang bagian tubuh yang senstif $27 \%$ dan $6 \%$ pernah melakukan hubungan seksual. Hasil survei Komisi Nasional Perlindungan Anak di 33 provinsi tahun 2008 di Indonesia didapatkan bahwa 97\% remaja SMP dan SMA pernah menonton film porno, 93,7\% remaja pernah ciuman, stimulasi genital dan seks oral, $62,7 \%$ sudah tidak perawan lagi, dan 21,2\% remaja mengaku pernah aborsi (Badan Pemberdayaan Masyarakat dan Perempuan dan Keluarga Berencana [BPMPKB], 2010).

Kota Depok yang dinobatkan sebagai "Kota Layak Anak" tentunya harus menjamin kesejahteraan hidup anak-anak yang tinggal di Kota Depok, sehingga tercipta kelayakan. Namun pada kenyataannya, masih ditemukan kasus-kasus pada anak. Menurut data Unit Perlindungan Perempuan dan Anak (PPA) Polres Depok, rata-rata terdapat 10 kasus persetubuhan remaja di bawah umur setiap bulan. Penelitian Nurhayati (2011) di Desa Tridaya Sakti, Bekasi menunjukkan bahwa terdapat hubungan antara umur, jenis kelamin, dan pola komunikasi serta kekuatan keluarga dengan perilaku seksual berisiko. Pada penelitian Kurnia (2008) di salah satu SMA Jabodetabek didapatkan hasil sebanyak 59,3\% (35 remaja) memiliki pengetahuan infeksi menular seksual rendah dan berperilaku seksual berisiko. Hasil tersebut menunjukkan bahwa terdapat hubungan yang bermakna antara tingkat pengetahuan infeksi menular seksual dengan perilaku seksual pranikah. Penelitian lain yaitu terkait gambaran agresivitas perilaku seksual remaja putra di SMA Jakarta Selatan oleh Dewi, Utami, Mutmainah, dan Devy (2011). Hasil penelitian menunjukkan adanya perilaku seksual remaja yang bersifat agresif sebesar $28 \%$.
Fungsi keluarga salah satunya yaitu fungsi afektif yang merupakan pemberian perlindungan psikologis, penciptaan rasa aman, pengadaan interaksi dan pengenalan identitas individu. Keberlangsungan interaksi dalam keluarga akan membentuk suatu kepribadian setiap anggota keluarga untuk mengungkapkan permasalahan dan sesuatu yang dialaminya. Adanya optimalisasi fungsi afektif dalam keluarga diharapkan menjadi dasar keluarga untuk menjamin anak yang telah remaja dalam keluarga terbebas dari segala masalah, khususnya pada remaja yang berisiko. Penelitian ini menjelaskan gambaran fungsi afektif keluarga dan perilaku seksual remaja.

\section{Metode}

Sebanyak 114 siswa dan siswi SMK X Kota Depok berpartisipasi pada penelitian ini. Pengambilan data dengan teknik cluster sampling dilakukan mulai dari Februari sampai Juni 2015. Analisis data dilakukan secara deskriptif.

Instrumen yang digunakan berupa kuesioner karakteristik responden, perilaku seksual remaja, dan kuesioner fungsi afektif keluarga. Kuesioner perilaku seksual diadopsi dari kuesioner yang digunakan pada penelitian Agustini (2003) tentang peranan pengetahuan HIV/AIDS dan tahapan moral judgment terhadap perilaku seksual pranikah pada remaja. Namun, pada penelitian ini tidak meneliti perilaku seksual berisiko HIV/AIDS. Perilaku seksual berisiko yang diteliti adalah risiko terhadap penularan penyakit menular seksual secara umum. Dengan demikian, pengkategorian menjadi perilaku seksual berisiko rendah (skor yang diberikan kepada responden adalah nol) dan perilaku seksual berisiko sedang-tinggi (skor yang diberikan kepada responden adalah satu).

Kuesioner fungsi afektif keluarga yang digunakan merupakan kuesioner hasil modifikasi dari penelitian Amalia (2009). Modifika- 
si yang dilakukan disesuaikan dengan pertanyaan pengkajian fungsi afektif berdasarkan teori Friedman (2010). Pengkategorian dari kuesioner tersebut adalah fungsi afektif adekuat dan tidak adekuat berdasarkan nilai mean, skor $\geq 38,31$ merupakan fungsi afektif keluarga kategori adekuat, dan skor < 38,31 masuk kategori fungsi afektif keluarga tidak adekuat.

Prosedur pengumpulan data dimulai dari mengurus perijinan hingga pengisian kuesioner penelitian berlandaskan etika penelitian. Analisis data dilakukan melalui tahapan yaitu editing, coding, processing, dan cleaning. Analisis data yang digunakan yaitu analisis univariat dengan uji proporsi.

\section{Hasil}

Responden penelitian perilaku seksual remaja adalah siswa yang masih tergolong pada usia remaja (usia 12-25 tahun dan belum menikah). Hasil penelitian digambarkan pada tabel 1 .

Tabel 1. Karakteristik Responden Berdasarkan Usia, Jenis Kelamin, Tempat Tinggal, dan Sumber Informasi

\begin{tabular}{lcc}
\hline \multicolumn{1}{c}{ Karakteristik } & Frekuensi & $\begin{array}{c}\text { Persentase } \\
(\mathbf{\%})\end{array}$ \\
\hline Usia & & \\
$\begin{array}{l}\text { Remaja Awal (12-16 } \\
\text { tahun) }\end{array}$ & 63 & 55,3 \\
Remaja akhir (17-25 & 51 & 44,7 \\
tahun) & & \\
Jenis Kelamin & & \\
Laki-Laki & 45 & 39,5 \\
Perempuan & 69 & 60,5 \\
& & \\
Tempat Tinggal & & \\
Bersama Keluarga & 112 & 98,2 \\
Kost & 2 & 1,8 \\
Sumber Informasi & & \\
Media cetak & 3 & 2,6 \\
Internet & 77 & 67,5 \\
Media Elektronik & 15 & 13,2 \\
Teman & 5 & 4,4 \\
Guru atau Orang tua & 5 & 4,4 \\
Lainnya & 9 & 7,9 \\
\hline
\end{tabular}

Tabel 1 menunjukkan karakteristik responden pada penelitian bahwa mayoritas responden berusia remaja awal pada rentang 12 tahun sampai dengan 16 tahun $(55,3 \%)$, berjenis kelamin perempuan $(60,5 \%)$, tinggal bersama orang tua atau keluarga $(98,2 \%)$, dan mendapatkan informasi tentang seksualitas melalui internet $(67,5 \%)$.

Tabel 2. Distribusi Fungsi Afektif Keluarga

\begin{tabular}{lcc}
\hline \multicolumn{1}{c}{ Kategori } & Frekuensi & Persentase (\%) \\
\hline Tidak adekuat & 55 & 48,2 \\
Adekuat & 59 & 51,8 \\
\hline
\end{tabular}

Tabel 2 menunjukkan bahwa responden dengan fungsi afektif adekuat lebih banyak dibandingkan responden dengan fungsi afektif tidak adekuat $(51,8 \%)$.

Tabel 3. Distribusi Perilaku Seksual Remaja

\begin{tabular}{lcc}
\hline \multicolumn{1}{c}{ Kategori } & Frekuensi & $\begin{array}{c}\text { Persentase } \\
(\%)\end{array}$ \\
\hline $\begin{array}{l}\text { Perilaku seksual berisiko } \\
\text { rendah }\end{array}$ & 108 & 94,7 \\
$\begin{array}{l}\text { Perilaku seksual berisiko } \\
\text { sedang sampai tinggi }\end{array}$ & 6 & 5,3 \\
\hline
\end{tabular}

Hasil analisis data menggambarkan bahwa mayoritas responden $(94,7 \%)$ memiliki perilaku seksual berisiko rendah.

Tabel 4 menggambarkan bahwa sebagian besar responden pada setiap karakteristik berperilaku seksual berisiko rendah. Persentase yang lebih tinggi pada perilaku seksual berisiko sedang sampai tinggi yaitu remaja akhir $(9,8 \%)$, laki-laki $(8,9 \%)$, tinggal bersama keluarga $(5,4 \%)$, dan sumber informasi internet $(3,9 \%)$. 
Tabel 4. Perilaku Seksual Remaja Berdasarkan Karakteristik

\begin{tabular}{|c|c|c|c|c|c|c|}
\hline \multirow{3}{*}{ Karakteristik } & \multicolumn{4}{|c|}{ Perilaku Seksual Remaja } & \multirow{2}{*}{\multicolumn{2}{|c|}{ Total }} \\
\hline & \multicolumn{2}{|c|}{$\begin{array}{l}\text { Berisiko } \\
\text { Rendah }\end{array}$} & \multicolumn{2}{|c|}{$\begin{array}{c}\text { Berisiko } \\
\text { Sedang- } \\
\text { Tinggi }\end{array}$} & & \\
\hline & $\mathbf{N}$ & $\%$ & $\mathbf{N}$ & $\%$ & $\mathbf{N}$ & $\%$ \\
\hline Usia & & & & & & \\
\hline $\begin{array}{l}\text { Remaja Awal } \\
\text { (12-16 tahun) }\end{array}$ & 62 & 98,4 & 1 & 1,6 & 63 & 100 \\
\hline $\begin{array}{l}\text { Remaja Akhir } \\
\text { (17-25 tahun) }\end{array}$ & 46 & 90,2 & 5 & 9,8 & 51 & 100 \\
\hline $\begin{array}{l}\text { Jenis } \\
\text { Kelamin }\end{array}$ & & & & & & \\
\hline Laki-laki & 41 & 91,1 & 4 & 8,9 & 45 & 100 \\
\hline Perempuan & 67 & 97,1 & 2 & 2,9 & 69 & 100 \\
\hline $\begin{array}{l}\text { Tempat } \\
\text { Tinggal }\end{array}$ & & & & & & \\
\hline $\begin{array}{l}\text { Bersama } \\
\text { Keluarga }\end{array}$ & 106 & 94,5 & 6 & 5,4 & 112 & 100 \\
\hline Kost & 2 & 100 & 0 & 0 & 2 & 100 \\
\hline $\begin{array}{l}\text { Sumber } \\
\text { Informasi }\end{array}$ & & & & & & \\
\hline Media Cetak & 3 & 100 & 0 & 0 & 3 & 100 \\
\hline Internet & 74 & 96,1 & 3 & 3,9 & 77 & 100 \\
\hline $\begin{array}{l}\text { Media } \\
\text { Elektronik }\end{array}$ & 14 & 93,3 & 1 & 6,7 & 15 & 100 \\
\hline Teman & 5 & 100 & 0 & 0 & 5 & 100 \\
\hline $\begin{array}{l}\text { Guru atau } \\
\text { orang tua }\end{array}$ & 5 & 100 & 0 & 0 & 5 & 100 \\
\hline Lain-lain & 7 & 77,8 & 2 & 22,2 & 9 & 100 \\
\hline
\end{tabular}

\section{Pembahasan}

Hasil penelitian mengenai fungsi afektif keluarga menunjukkan bahwa mayoritas remaja memiliki fungsi afektif adekuat. Hasil ini sejalan dengan penelitian Rahmadita (2012) tentang fungsi afektif keluarga pada siswa lakilaki (13-15 tahun) di SMP 3 Ungaran. Penelitian Manik (2009), juga menyatakan bahwa fungsi afektif pada mahasiswa memiliki kategori adekuat. Hal tersebut membuktikan bahwa sebagian besar keluarga memiliki fungsi afektif yang baik atau adekuat. Oleh karena itu, dapat diartikan bahwa sebagian besar keluarga remaja di SMK X Kota Depok memiliki hubungan yang baik dalam hal saling menghormati hak-hak anggota keluarga khususnya hak anak remaja. Menurut Pappini dan Sebby (1987), pada masa remaja, remaja cenderung meniru orang lain dan memberikan elaborasi mengenai sifat afektif hubungan keluarga kemudian mengimplementasikan dalam kehidupan pribadinya.

Hasil analisis tentang perilaku seksual remaja menunjukkan bahwa mayoritas responden berperilaku seksual berisiko rendah. Hasil penelitian ini konsisten dengan penelitian Utami (2012) mengenai hubungan peer group dengan perilaku seksual remaja yang menunjukkan bahwa sebagian besar remaja memiliki perilaku seksual yang aman. Hal ini berbeda dengan hasil Survei Kesehatan Reproduksi Remaja Indonesia (SKRRI) tahun 2002-2003 yang menemukan remaja yang pernah berhubungan seksual pada usia 14-19 tahun untuk perempuan sebanyak $34,7 \%$ dan laki-laki sebanyak 30,9\%. Hasil survey Komnas Perlindungan Anak di 33 provinsi tahun 2008 di Indonesia didapatkan bahwa $97 \%$ remaja SMP dan SMA pernah menonton film porno, $93,7 \%$ remaja pernah ciuman, stimulasi genital dan seks oral, $62,7 \%$ sudah tidak perawan lagi, dan 21,2\% remaja mengaku pernah aborsi (Badan Pemberdayaan Masyarakat dan Perempuan dan Keluarga Berencana, 2010).

Perilaku seksual berisiko yang tidak terkontrol atau terlindungi akan berdampak pada risiko penularan HIV, infeksi menular seksual, dan kehamilan yang tidak direncanakan. Menurut Guttmancher Institute (2006) sekitar 750.000 kehamilan terjadi pada remaja setiap tahunnya, dan $82 \%$ merupakan kehamilan tidak diinginkan (Cox, Fasolini, \& Tavakoli, 2008).

Penelitian yang dilakukan oleh Caal (2008) tentang keputusan dalam perlindungan terhadap perilaku seksual pada sampel 254 remaja Afrika Amerika usia 12-21 tahun, menunjukkan bahwa self-efficacy (kemampuan remaja untuk melindungi diri) terbukti paling dapat diandalkan sebagai perlindungan terhadap perilaku seksual. Penelitian Harden dan Mandle (2010) tentang peran konteks hubungan peri- 
laku seksual remaja dengan kenakalan remaja pada 519 pasangan kembar sesama jenis (48,6\% wanita) dibagi menjadi dua kelompok umur (13-15 dan 16-18 tahun usia) yang diambil dari National Longitudinal Study of Adolescent Health di Amerika Serikat menunjukkan bahwa untuk kedua remaja muda dan tua, gen yang mendasari umumnya memengaruhi baik perilaku seksual dan kenakalan. Setelah mengontrol pengaruh genetik ini, ada hubungan antara aktivitas seksual dan kenakalan pada remaja muda. Penelitian lain oleh Schoeny (2010) mengenai asosiasi longitudinal dengan perilaku seksual remaja menunjukkan bahwa orang tua memainkan peran penting untuk intervensi keluarga dalam pencegahan risiko seksual.

Hasil penelitian menunjukkan bahwa angka kejadian perilaku seksual remaja minoritas, tetapi tidak dipungkiri bahwa perilaku seksual berisiko rendah dapat berkembang menjadi perilaku seksual berisiko tinggi jika tidak ada pengawasan dari guru atau orang tua remaja tersebut.

Variabel perilaku seksual remaja dijabarkan berdasarkan karakteristik responden. Karakteristik responden yang akan dibahas antara lain usia, jenis kelamin, tempat tinggal, dan sumber informasi.

Karakteristik pertama yaitu usia remaja. Persentase perilaku seksual remaja sedang sampai tinggi paling banyak ditunjukkan oleh remaja pada usia remaja akhir. Penelitian yang dilakukan Odeyemi, Onajole, dan Ogunowo (2009) di Lagos, Nigeria, menunjukkan banyak remaja putri $(43,7 \%)$ telah melakukan hubungan seksual dengan rerata usia 16 tahun. Alasan utama untuk melakukan hubungan seksual adalah rasa ingin tahu. Penelitian ini memperkuat fakta bahwa usia mempengaruhi perilaku seksual remaja.

Karakteristik kedua yaitu jenis kelamin. Hasil penelitian menunjukkan persentase laki-laki lebih banyak yang berperilaku seksual berisiko sedang sampai tinggi. Hal ini sejalan dengan penelitian Musthofa dan Winarti (2009-2010) yang menunjukkan bahwa laki-laki mempunyai persentase lebih besar untuk melakukan perilaku seksual berisiko.

Karakteristik selanjutnya adalah ketersediaan sumber informasi. Remaja dengan persentase berperilaku seksual berisiko sedang sampai tinggi, mendapatkan informasi melalui internet. Hasil penelitian Musthofa dan Winarti (2009-2010), menunjukkan bahwa remaja yang melakukan perilaku seksual berisiko lebih banyak dijumpai pada remaja yang mempunyai akses pornografi tinggi. Pornografi dapat mengakibatkan perilaku negatif seperti mendorong anak meniru tindakan seksual, membentuk sikap, nilai dan perilaku yang negatif (Peacevmaker, 2012).

\section{Kesimpulan}

Penelitian ini menjelaskan bahwa para remaja yang memiliki fungsi afektif keluarga yang adekuat memiliki kecenderungan berperilaku seksual berisiko rendah (YA, HR, AM).

\section{Referensi}

Agustini, N. (2003). Peranan pengetahuan HIV/AIDS dan tahapan moral judgment terhadap perilaku seksual pranikah pada remaja. (Tesis, tidak dipublikasikan). Fakultas Ilmu Keperawatan Universitas Indonesia, Depok, Jawa Barat, Indonesia.

Amalia, R. (2008). Hubungan fungsi afektif keluarga dengan prestasi belajar mahasiswa Fakultas Ilmu Keperawatan Universitas Indonesia asal daerah (Skripsi, tidak dipublikasikan). Fakultas Ilmu Keperawatan Universitas Indonesia, Depok, Jawa Barat, Indonesia.

Badan Pusat Statistik. (2010). Penduduk menurut wilayah dan agama yang dianut. Diperoleh dari http://sp2010.bps.go.id/index.php/site/tab el wid $=0000000000 \&$ tid $=321 \&$ fil $=58 \&$ fi $=1$ 
BKKBN. (2011). Kajian profil penduduk remaja (10-24 tahun). Jakarta: Pusat Penelitian dan Pengembangan Kependudukan.

BPMPKB. (2010). Panduan pengelolaan pusat informasi dan konseling remaja (PIK Remaja). Jakarta: BPMPKB.

Caal, N.S. (2008). Adolescent sexual development: Contextualizing a cognitive process in the decision to engage in protective or risky sexual behavior (Disertasi Doktor). Diperoleh dari Proques Dissertations and Theses (UMI No 3305907).

Centers for Disease Control and Prevention. (2009). Youth risk behavior surveillance: United States. Surveillance Summaries, 59 (SS-5).

Cox, M.F., Fasolino, T.K., \& Tavakoli, A.S (2008). Factor analysis and psychometric properties of the Mother-Adolescent Sexual Communication (MASC) instrument for sexual risk behavior. Journal of Nursing Measurement, 16 (3), 171-183.

Depkes RI. (2009). Pedoman pelayanan kesehatan peduli remaja di puskesmas. Jakarta: Departemen Kesehatan Republik Indonesia.

Kementrian Komunikasi dan Informatika. (2013). Pengguna internet di Indonesia 63 juta orang. Diperoleh dari http://kominfo.go.id/index.php /content/detail/3415/Kominfo+\%3A+Penggun a+Internet+di+Indonesia+63+Juta+Orang/0/be rita_satker

Kurnia, D.A. (2008). Hubungan tingkat pengetahuan infeksi menular seksual dengan perilaku seksual pranikah (Skripsi, tidak dipublikasikan). Universitas Indonesia, Depok, Jawa Barat, Indonesia.

Dewi, A.K., Utami, I.T., Mutmainah, \& Devy, S. (2011). Gambaran agresivitas perilaku seksual remaja di Jakarta Selatan. (Skripsi sarjana, tidak dipublikasikan). Fakultas Ilmu Keperawatan Universitas Indonesia, Depok, Jawa Barat, Indonesia.

Manik, F.D. (2009). Hubungan pola belajar dengan fungsi afektif keluarga pada mahasiswa regular angkatan 2008 Fakultas Ilmu Keperawatan Universitas Indonesia. (Skripsi sarjana, tidak dipublikasikan). Universitas Indonesia, Depok, Jawa Barat, Indonesia.

Musthofa, Syamsulhuda, B., \& Winarti, P. (2010). Faktor yang maempengaruhi perilaku seks pranikah mahasiswa di Pekalongan tahun 2009-2010. Jurnal Kesehatan Reproduksi, 1, $32-41$.

Nurhayati. (2011). Hubungan pola komunikasi dan kekuatan keluarga dengan perilaku seksual berisiko di Desa Tridaya Sakti. (Tesis Magister, tidak dipublikasikan). Fakultas Ilmu Keperawatan Universitas Indonesia, Depok, Jawa Barat, Indonesia.

Odeyemi, K., Onajole, A., \& Ogunowo, B. (2009). Sexual behavior and the influencing factors among out of school female adolescents in Mushin market, Lagos, Nigeria. National Lybrary of Medicine, 21 (1), 101-109.

Pappini, D.R., \& Sebby, R.A. (1987). Adolescent pubertal status and affective family relationships: A multivariate assessment. Journal of youth and adolescence, 16, 1-15.

Peacevmaker. (2012). Pornografi lebih berbahaya dari narkoba. Diperoleh dari http://health.oke zone.com.9.54.htm

Rahmadita. (2012). Hubungan pelaksanaan peran dan fungsi afektif keluarga terhadap derajat merokok pada perokok aktif siswa laki-laki (13-15 tahun) di SMP 3 Ungaran. (Skripsi sarjana, tidak dipublikasikan). PSIK STIKes Ngudi Waluyo Ungaran, Semarang, Jawa Tengah.

Schoeny, M.E. (2010). How can parents make a difference? Longitudinal associations with adolescent sexual behavior. Journal of Family Psychology, 24 (6), 731-739.

USAID. (2013). Pelayanan kesehatan reproduksi remaja. Diperoleh dari https://www.k4health. org/toolkits/indonesia/pelayanan-kesehatanreproduksi-remaja. 
Utami, P.P. (2012). Hubungan peer group dengan perilaku seksual remaja di SMA N 103 Jakarta Timur (Skripsi sarjana, tidak dipublikasikan). Fakultas Ilmu Keperawatan Universitas Indonesia, Depok, Jawa Barat, Indonesia. 